
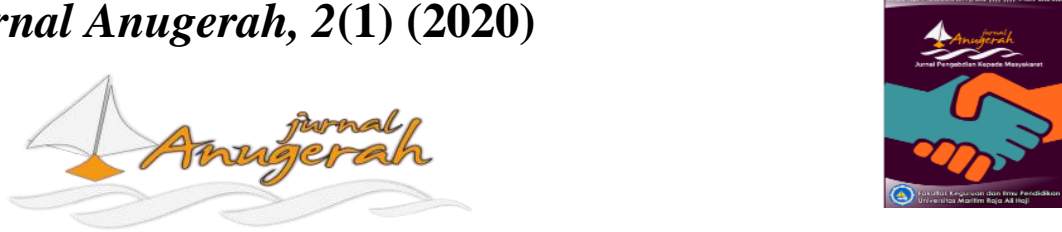

e-ISSN 2715-8179

https://ojs.umrah.ac.id/index.php/anugerah

\title{
Pelatihan Model-Model Pembelajaran Inovatif untuk Guru di Sekolah Menengah Pertama Negeri 7 Kota Bengkulu
}

\author{
Fina Hiasa ${ }^{1^{*}}$, Emi Agustina ${ }^{2}$ \\ ${ }_{1,2}$ Universitas Bengkulu, Kota Bengkulu, Provinsi Bengkulu 38371, Indonesia \\ *e-mail korespondensi: finahiasa@unib.ac.id
}

Pengiriman: 22 November 2019: 24 Mei 2020; Publikasi: 31 Mei 2020

DOI: https://doi.org/10.31629/anugerah.v2i1.1597

\begin{abstract}
Abstrak
Tujuan pelatihan ini adalah untuk meningkatkan pemahaman dan keterampilan para guru di SMPN 7 Kota Bengkulu mengenai model pembelajaran inovatif. Metode yang digunakan dalam kegiatan ini adalah metode pelatihan dengan ceramah dan tanya jawab serta demonstrasi yang dilakukan oleh beberapa guru dengan menerapkan model pembelajaran yang inovatif. Peserta dalam kegiatan ini adalah dewan guru SMPN 7 Kota Bengkulu yang berjumlah 13 orang. Instrumen yang digunakan dalam pelatihan ini adalah angket. Tim pelaksana membagikan angket untuk mengetahui ada atau tidaknya peningkatan pengetahuan peserta pelatihan sebelum dan sesudah pelatihan diadakan. Hasilnya adalah terjadi peningkatan pengetahuan guru tentang model pembelajaran inovatif yaitu sebagai berikut, pengetahuan awal $45 \%$, pengetahuan tentang teknik pelaksanaan sebesar $50 \%$, pengetahuan mendalam sebesar $50 \%$, dan pengetahuan tentang referensi sebesar $45 \%$.
\end{abstract}

Kata kunci: pelatihan; guru; model pembelajaran inovatif

\begin{abstract}
The purpose of this training is to improve the understanding and skills of teachers at Bengkulu 7 Middle School regarding innovative learning models. The method used in this activity is the training method with lectures and questions and answers and demonstrations conducted by several teachers by applying an innovative learning model. Participants in this activity were the board of teachers of SMPN 7 Bengkulu City, totaling 13 people. The instrument used in this training was a questionnaire. The implementation team distributed questionnaires to find out whether or not there was an increase in the knowledge of training participants before and after the training was held. The result is an increase in teacher knowledge about innovative learning models as follows, initial knowledge 45\%, knowledge of implementation techniques by 50\%, in-depth knowledge by 50\%, and knowledge about references by $45 \%$.
\end{abstract}

Keywords: training; teacher; innovative learning model

\section{Pendahuluan}

Berdasarkan undang-undang nomor 20 Tahun 2003 tentang Sistem Pendidikan Nasional terdapat rumusan mengenai apa itu pendidikan. Menurut Depdiknas (2003) pendidikan adalah usaha sadar dan terencana untuk mewujudkan suasana belajar dan proses pembelajaran agar peserta didik secara aktif mengembangkan potensi dirinya agar dapat memiliki kekuatan spritual keagamaan, pengendalian diri, kepribadian, kecerdasan akhlak mulia, serta keterampilan yang diperlukan bagi masyarakat, bangsa, dan negara. Artinya pendidikan 
memiliki dampak penting bagi individu untuk membentuk diri menjadi manusia yang manusiawi bagi masyarakat, bangsa, dan negara. Pembentukan diri tersebut tidak terlepas dari peran yang terdapat di dalam diri dan diluar diri. Ada beberapa hal yang berasal dari luar diri yang mempengaruhi keberhasilan seseorang dalam menjalani pendidikan sehingga menjadi manusia yang manusiawi misalnya saja fasilitas sarana dan prasarana, lingkungan belajar yang mendukung, serta pendidik yang mumpuni.

Pendidik sebagai penyalur sekaligus pengawas ilmu yang diberikan kepada peserta didik memiliki kewajiban untuk memiliki kompetensi sebagai seorang pendidik. Undang-undang Republik Indonesia Nomor 14 Tahun 2005 tentang guru dan dosen pasal 1 ayat 10 menyebutkan kompetensi adalah seperangkat pengetahuan, keterampilan, dan perilaku yang harus dimiliki, dihayati, dan dikuasai oleh guru atau dosen dalam melaksanakan keprofesionalan. Guru sebagai seorang pendidik dalam bidang pendidikan memiliki kewajiban untuk memenuhi kompetensi profesionalnya. Hal ini berimplikasi bahwa guru harus mengembangkan kompetensinya secara berkelanjutan, termasuk jika terjadi transformasi zaman (Astuti \& Febrian, 2019). Suyanto dan Djihad dalam Yayah dan Nurdin (2012) mengatakan kompetensi profesional merupakan kemampuan penguasaan materi pembelajaran secara luas dan mendalam yang meliputi: (a) konsep, strukur, dan metode keilmuan/ teknologi/ seni yang menaungi/koheren dengan materi ajar; (b) materi ajar yang ada dalam kurikulum sekolah; (c) hubungan konsep antar mata pelajaran terkait; (d) penerapan konsep-konsep keilmuan dalam kehidupan sehari-hari; dan (e) kompetensi secara profesional dalam konteks global dan dengan tetap melestarikan nilai dan budaya nasional. Agar dapat dikatakan professional, seorang guru harus memiliki standar mutu dan juga mengikuti pendidikan profesi.

Depdiknas dalam Sanusi (1991) merumuskan standar kerja yang harus dimiliki oleh seorang guru. Standar tersebut tertuang sebagai sepuluh kemampuan dasar kerja guru yaitu (1) guru dituntut untuk menguasai bahan pengajaran; (2) guru mampu mengelola program belajar dan mengajar; (3) guru mampu mengelola kelas; (4) guru mampu menggunakan media dan sumber pengajaran; (5) guru mampu menguasai landasan-landasan kependidikan; (6) guru mampu mengelola proses belajar mengajar; (7) guru mampu melaksanakan evaluasi pengajaran; (8) guru mampu melaksanakan layanan bimbingan dan penyuluhan; (9) guru mampu membuat administrasi sekolah; (10) guru mampu melaksanakan penelitian tindakan kelas (PTK). Berdasarkan uraian sebelumnya dapat disimpulkan bahwa seorang pendidik haruslah dapat menghadirkan suasana belajar yang bermanfaat pagi kepentingan peserta didik. Dibutuhkan inovasi dalam kegiatan pembelajaran agar kebermanfaatan kegiatan belajar mengajar terasa menyenangkan untuk dijalani oleh peserta didik. Salah satu strategi untuk mencapai pembelajaran yang bermakna dan menyenangkan adalah dengan menerapkan model pembelajaran inovatif kepada peserta didik. Hal inilah yang menjadi fokus dari tim pelaksana pengabdian yaitu dengan memberikan pelatihan tentang model-model pembelajaran inovatif kepada para guru.

Survei awal yang dilakukan oleh tim pelaksana pengabdian adalah mengunjungi sekolah-sekolah yang dianggap tepat untuk dijadikan mitra dalam pelaksanaan kegiatan ini. Tim pelaksana kegiatan mengobservasi beberapa sekolah yang bukan unggulan dan melihat bagaimana kegiatan pembelajaran berlangsung. Berdasarkan hasil observasi secara langsung dengan melihat ke dalam kelas dan mewawancarai beberapa orang guru, maka dipilihlah SMPN 7 Kota Bengkulu sebagai mitra pengabdian. Guru-guru SMPN 7 Kota Bengkulu cenderung mengajar dengan gaya yang konvensional dan komunikasi yang terjadi ketika kegiatan belajar mengajar cenderung satu arah sehingga minim keterlibatan siswa sebagai peserta didik. Hal tersebut terjadi karena minimnya pelatihan yang diikuti khususnya tentang inovasi dalam kegiatan pembelajaran. Hal ini membuat pembelajaran cenderung bergaya konvensional dan kurang memanfaatkan media dan sumber pembelajaran yang mendukung suasana pembelajaran menjadi interaktif.

Situasi pembelajaran yang cenderung monoton dan satu arah tersebut tentu saja bertentangan dengan standar kerja yang harus dimiliki oleh seorang guru yang seharusnya dapat mengelola kelas dan memanfaatkan media serta sumber pengajaran yang ada. Berdasarkan situasi tersebut, maka diperlukan 
pelatihan berkaitan dengan model pembelajaran inovatif agar kegiatan belajar mengajar tidak hanya bermakna tetapi juga menyenangkan bagi peserta didik dan pendidik yang salah satunya adalah model cooperative learning. Slavin (2009) mengatakan pembelajaran kooperatif merujuk pada berbagai macam metode pengajaran di mana para siswa bekerja dalam kelompok-kelompok kecil untuk saling membantu satu sama lainnya dalam mempelajari materi pelajaran". Siswa akan saling bekerja sama dengan siswa lainnya secara berkelompok untuk mempelajari suatu topik. Pada kelompok tersebut, siswa akan saling membantu dalam membentuk konsep awal dan juga menemukan penyelesaian dalam suatu permasalahan. Diskusi akan diadakan dalam kelompok kecil yang akan dipresentasikan dalam kelompok besar (kelas) itu sendiri. Model pembelajaran ini akan lebih banyak melibatkan siswa dengan memberikan kebebasan kepada para siswa untuk menemukan konsep awal serta memecahkan masalah. Model pembelajaran inovatif yang menjadi materi pada pengabdian ini adalah model NHT, Project Based Learning, Analisis Kasus, dan model pembelajaran kooperatif Jigsaw.

Pelatihan sejenis pernah dilakukan oleh Widodo dkk. (2017) yang menyimpulkan adanya peningkatan peserta pelatihan dari kategori kurang pada tes awal menjadi baik pada tes akhir. Pada tes awal menunjukkan pemahaman peserta pelatihan tentang model-model pembeljaran inovatif tergolong cukup dengan nilai rata-rata 52,76 sedangkan pada tes akhir pemahaman peserta tergolong baik dengan nilai ratarata 82,64. Selain itu, terdapat pula pelatihan yang dilakukan oleh Sri Sumaryati (2013) dengan hasil yaitu (1) $90 \%$ of participants attending the training and mentoring diligently performed 4 times. (2) $75 \%$ are able to draw up lesson plans on the subject matter by using a model of innovative learning.

Pentingnya kualitas guru dalam kegiatan pembelajaran inilah yang menjadi pusat perhatian tim pelaksana pengabdian. Sasarannya adalah peningkatan kualitas guru dalam segi pengetahuan terhadap model pembelajaran inovatif yang harapannya terjadi peningkatan kualitas dalam kegiatan belajar mengajar di kelas. Kualitas tersebut berbanding lurus dengan implementasi variasi model-model pembelajaran oleh guru di dalam kelas. Maka dari itu narasumber pada pelatihan ini adalah tim pelaksana yang mewakili institusi Universitas Bengkulu yang bertugas memenuhi kebutuhan para guru akan pengetahuan tentang model pembelajaran inovatif. Tujuannya adalah agar guru dapat meningkatkan kualitas diri agar dapat mengajar secara menyenangkan dan bermakna bagi siswa sehingga sekolah dapat menghasilkan siswa-siswa berprestasi.

\section{Metode}

Metode yang digunakan pada kegiatan ini adalah pelatihan untuk guru di SMPN 7 Kota Bengkulu. Pelatihan dilakukan untuk menambah pengetahuan dan wawasan guru tentang model-model pembelajaran inovatif. Setelah guru sasaran menguasai pengetahuan tersebut, selanjutnya mereka diminta untuk menerapkan pengetahuan tersebut dalam kegiatan belajar mengajar di dalam kelas. Tim dosen akan mengarahkan, membimbing, dan membantu guru sasaran selama pelatihan dan setelah pelatihan jika para guru menginginkan tanya jawab diluar sesi pelatihan. Berikut adalah metode yang digunakan ketika pengabdian berlangsung:

1. Ceramah dan Tanya Jawab. Metode ini dipilih untuk menjelaskan tentang materi yang bersifat teoritik terkait model-model pembelajaran yang menarik dan inovatif.

2. Demonstrasi. Metode ini digunakan untuk menjelaskan suatu proses kerja secara bertahap sehingga dapat memberi kemudahan bagi peserta. Pada pelaksanaan pengabdian ini, perwakilan guru diminta untuk mendemonstrasikan pengetahuan tentang model inovatif yang telah dielaskan oleh narasumber.

Evaluasi dilaksanakan dengan cara memberikan angket kepada peserta pelatihan yang dibagi menjadi dua tahap. Tahap pertama dilakukan sebelum pelaksanaan pelatihan untuk mengetahui wawasan dan motivasi para guru sebagai khalayak sasaran dan tahap kedua dilaksanakan selama khalayak sasaran mengikuti pelaksanaan pelatihan. Kegiatan pengabdian ini dikatakan berhasil jika ada perubahan khalayak sasaran dari segi pengetahuan dan teknik dalam mengaplikasikan model pembelajaran. Indikator keberhasilan dapat dilihat dari kemampuan guru menerapkan pengetahuan tentang model-model 
pembelajaran yang menarik dan inovatif di dalam kelompok kecil selama pelatihan. Selanjutnya diharapkan guru akan menerapkan model-model pembelajaran tersebut dalam kelas sebenarnya. Sedangkan tolak ukur keberhasilan dalam pelatihan ini adalah para guru SMPN 7 Kota Bengkulu memiliki pemahaman dan mampu menerapkan model-model pembelajaran yang menarik dan inovatif.

\section{Hasil dan Pembahasan}

Sebelum memulai kegiatan pelatihan, tim pelaksana pengabdian telah membagikan angket awal kepada para guru tentang pengetahuan dan pelaksanaan model-model pembelajaran inovatif di dalam kelas. Hasilnya adalah guru mengetahui adanya model-model pembelajaran inovatif namun belum terlalu memahami mengenai penerapan model-model pembelajaran inovatif tersebut di dalam kelas. Berikut adalah diagram yang menunjukkan persentase pengetahuan awal guru terhadap model pembelajaran inovatif.

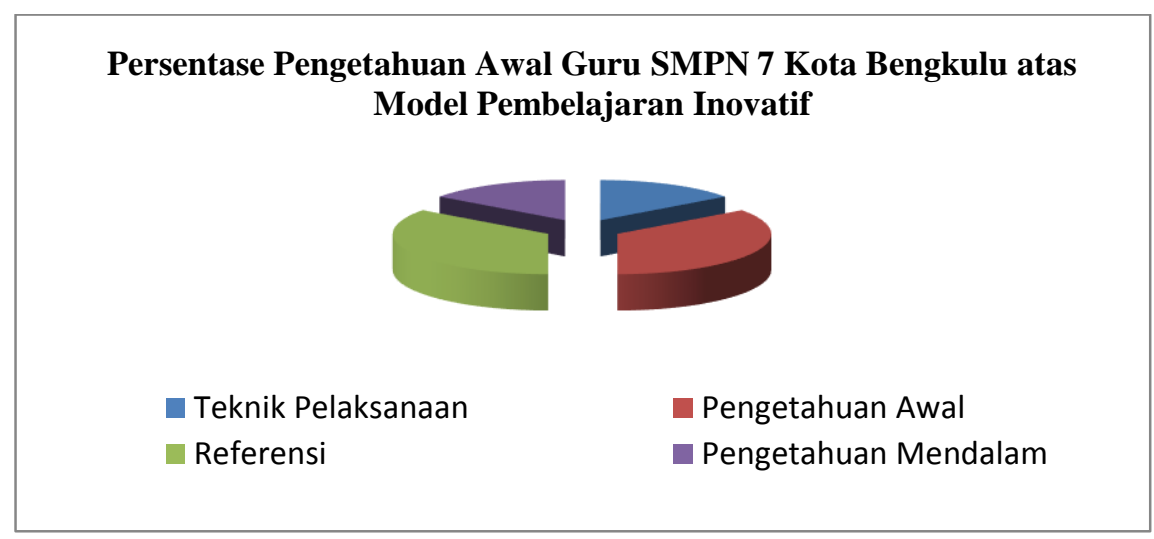

Gambar 1. Diagram Persentase Pengetahuan Awal Guru SMPN 7

Diagram di atas menunjukan persentase pengetahuan guru mengenai model pembelajaran inovatif. Pertama, sebanyak 35\% guru memiliki pengetahuan awal mengenai model pembelajaran inovatif. Pengetahuan awal ini meliputi pemahaman mengenai apa itu model pembelajaran inovatif dan apa saja macam-macam model pembelajaran inovatif. Kedua, sebanyak 15\% guru SMPN 7 Kota Bengkulu mengetahui tentang pengetahuan mendalam perihal model pembelajaran inovatif. Hasil ini menunjukkan bahwa masih rendahnya pemahaman mendalam yang dimiliki para guru mengenai model pembelajaran inovatif. Pengetahuan mendalam ini meliputi pemahaman terhadap tiap-tiap jenis model pembelajaran inovatif dan pemahaman langkah-langkah dalam penerapan model pembelajaran inovatif. Ketiga, adalah mengenai teknik pelaksanaan dalam penerapan model pembelajaran inovatif yaitu sebesar $15 \%$. Persentase tersebut tentu saja cukup rendah. Hasil ini senada dengan hasil wawancara awal dengan para guru yang cenderung terbiasa menerapkan model pembelajaran konvensional yang artinya komunikasi yang terjadi ketika pembelajaran berlangsung adalah satu arah. Teknik pelaksanaan meliputi praktik yang dilakukan guru di dalam kelas contohnya adalah bagaimana guru memosisikan siswa dan memosisikan diri ketika menggunakan model pembelajaran project based learning. Contoh lainya, bagaimana guru menyiapkan bahan dan meminta siswa menyiapkan bahan untuk memulai pembelajaran menggunakan model pembelajaran numbered head together.

Selain faktor kurangnya pengetahuan mendalam dan teknik pelaksanaan, faktor lain yang menyebabkan rendahnya pengetahuan mengenai model-model pembelajaran inovatif adalah kurangnya pengetahuan tentang referensi, dan lain-lain. Keempat, para peserta memiliki pengetahuan referensi sebesar $35 \%$ atas model pembelajaran inovatif. Di mana referensi yang dimaksud adalah pengetahuan mendapatkan bahan materi yang valid mengenai model pembelajaran inovatif dari berbagai sumber misalnya buku atau pun artikel yang terdapat di jurnal online. Pengabdian yang berfokus pada memberi pengetahuan tentang 
model pembelajaran inovatif ini mengambil referensi dari buku berjudul Model-model Pembelajaran Inovatif oleh Sugiyanto (2008) dan juga sumber internet lainnya yang ditransformasikan ke dalam bentuk slide powerpoint yang digunakan ketika pelatihan berlangsung.

Pelatihan model pembelajaran inovatif ini dilaksanakan di SMPN 7 Kota Bengkulu yang pesertanya adalah para guru di sekolah tersebut yaitu sebanyak 13 orang guru. Fokus penyampaian materi oleh tim pelaksana pengabdian yang dilaksanakan di SMPN 7 Kota Bengkulu adalah tentang model-model pembelajaran inovatif yang berkaitan dengan peningkatan kualitas pembelajaran di kelas. Media yang digunakan dalam pengabdian ini adalah infokus $(L C D)$ dan fotokopi slide powerpoint yang berisi materi mengenai pengetahuan model-model pembelajaran inovatif.

Pada sesi pertama penyampaian materi berkaitan dengan model pembelajaran inovatif yang menjelaskan definisi, alasan mengapa harus menggunakan model-model pembelajaran inovatif, dan macammacam model pembelajaran inovatif. Selanjutnya materi dilanjutkan dengan menyampaikan kepada para peserta mengenai langkah-langkah yang harus dilakukan dalam penerapan model-model pembelajaran inovatif di dalam kelas yaitu model NHT, Project Based Learning, Analisis Kasus, dan model pembelajaran kooperatif Jigsaw. Berikut adalah beberapa slide powerpoint yang berisi materi yang disampaikan oleh tim pelaksana pengabdian.

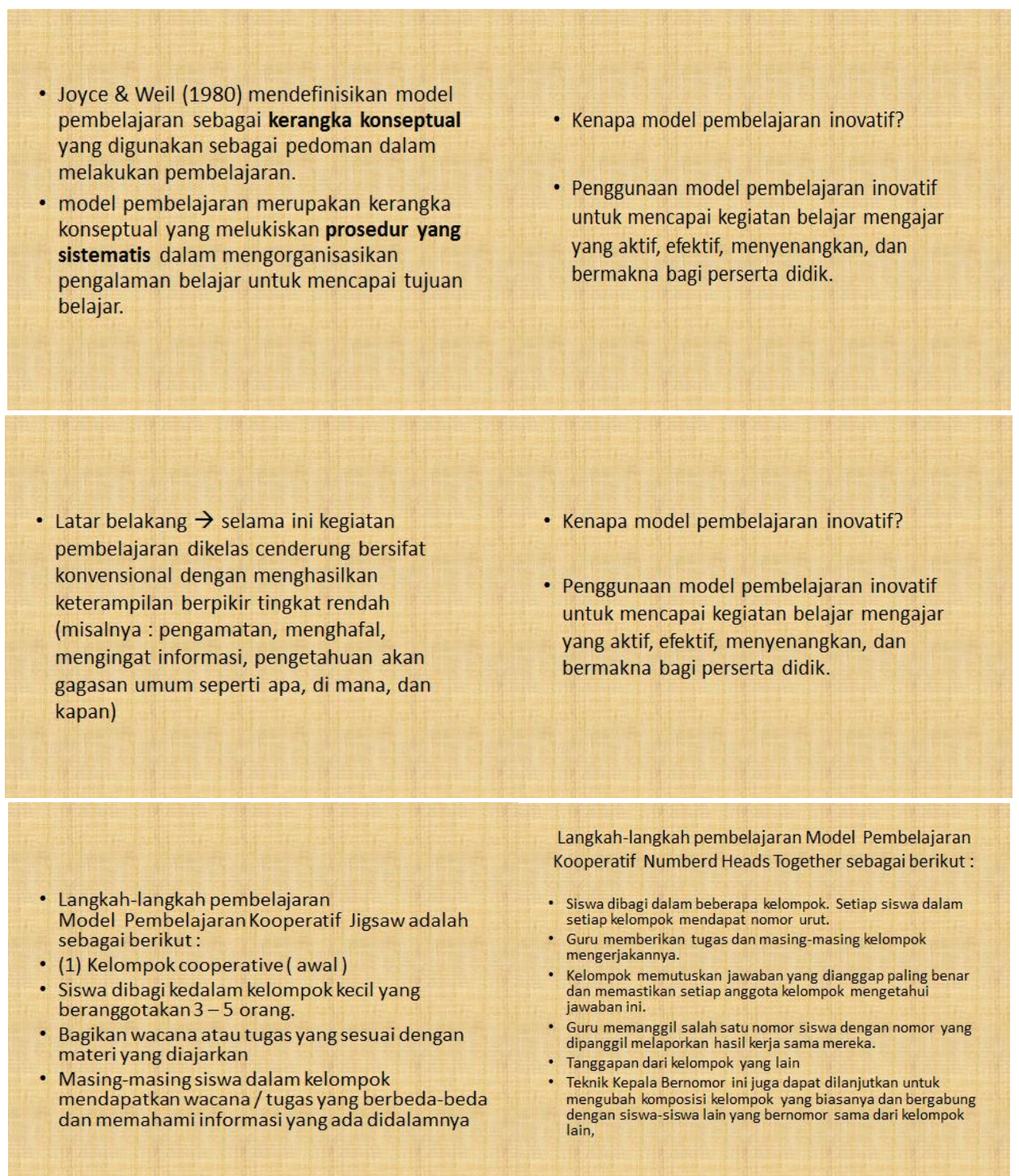

Gambar 2. Materi yang Disajikan 
Selain menjelaskan mengenai model-model pembelajaran inovatif, sesi dilanjutkan dengan kegiatan tanya jawab dengan para peserta perihal teknis pelaksanaan dalam penerapan model-model pembelajaran inovatif di dalam kelas. Bayangan kendala dalam pelaksanaan di dalam kelas yang disampaikan oleh guru juga dibahas secara bersama-sama pada sesi tersebut. Selanjutnya dilaksanakan praktik penerapan modelmodel pembelajaran inovatif dengan peran ada guru yang menjadi pengajar dan ada guru yang berperan sebagai siswa. Berikut adalah bukti pendukung yang menggambarkan kegiatan penyampaian materi pada pelaksanaan pengabdian di SMPN 7 Kota Bengkulu.

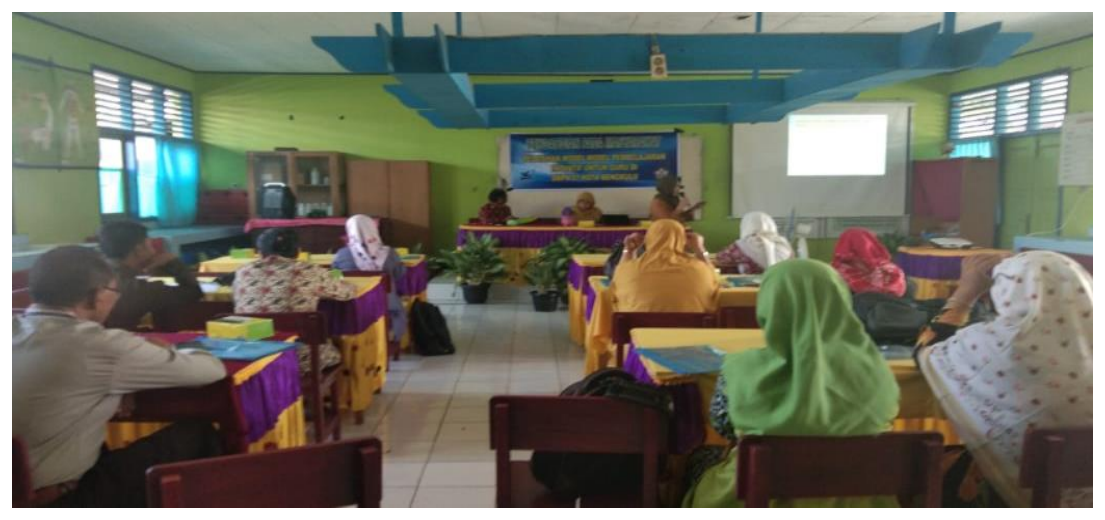

Gambar 3. Tim Pelaksana Pengabdian Menyampaikan Materi Kepada Guru SMPN 7 Kota Bengkulu

Pada akhir pelaksanaan pengabdian, tim pelaksana membagikan angket sebagai alat yang digunakan untuk mengukur seberapa besar capaian peningkatan pengetahuan peserta, mulai dari teknik pelaksanaan dalam penerapan model-model pembelajaran inovatif hingga referensi mengenai model-model pembelajaran tersebut. Berdasarkan angket pertama dan angket akhir yang tim pelaksana berikan kepada peserta pelatihan ditemukannya peningkatan persentase pengetahuan peserta, mulai dari teknik pelaksanaan dan lain-lain yang tergambar pada tabel berikut ini.

Tabel 1

Persentase Peningkatan Pengetahuan Peserta

\begin{tabular}{ccccc}
\hline & & Sebelum Pelatihan & Setelah Pelatihan & \\
\cline { 3 - 4 } No & Indikator Penilaian & Persentase tingkat & Persentase tingkat & Ratio \\
\cline { 3 - 5 } & & pemahaman & pemahaman & Peningkatan \\
\hline 1 & Teknik pelaksanaan & 15 & $65 \%$ & $50 \%$ \\
3 & Pengetahuan awal & 35 & $80 \%$ & $50 \%$ \\
4 & Pengetahuan mendalam & 15 & $65 \%$ & $45 \%$ \\
\hline
\end{tabular}

Berdasarkan data pada tabel tersebut diketahui bahwa ada peningkatan pemahaman peserta pelatihan pada aspek; pengetahuan awal, teknik pelaksanaan, pengentahuan mendalam, dan referensi. Pada indikator teknik pelaksanaan, terjadi peningkatan yaitu sebelum pelatihan $15 \%$ dan setelah pelatihan menjadi $65 \%$. Artinya untuk indikator tersebut terjadi peningkatan sebanyak 50\%. Hal serupa juga terjadi untuk indikator 
pengetahuan awal dan pengetahuan mendalam. Saat sebelum pelatihan, persentase yang di dapat yaitu pengetahuan awal (35\%) dan pengetahuan mendalam (15\%). Namun, setelah pelatihan dilaksanakan, persentase pun meningkat menjadi $65 \%$ untuk pengetahuan mendalam dan $80 \%$ untuk pengetahuan awal. Artinya terjadi peningkatan sebanyak $45 \%$ untuk pengetahuan awal dan $50 \%$ untuk pengetahuan mendalam. Indikator terakhir adalah pengetahuan tentang referensi. Sebelum pelatihan persentase yang diperoleh adalah $35 \%$ namun setelah pelatihan menjadi $80 \%$ artinya terjadi rasio peningkatan sebanyak 45 pada indikator referensi.

Pada saat melaksanakan kegiatan pengabdian, tim pengabdi juga menemukan beberapa faktor yang mendukung dan menghambat kegiatan pengabdian. Beberapa hal yang mendukung berjalannya kegiatan pengabdian adalah antusisme para peserta pelatihan. Antusiasme dibuktikan dengan banyaknya pertanyaan yang muncul ketika pelaksanaan tanya jawab. Selain itu pada saat praktik penerapan model pembelajaran inovatif para guru serius melaksanakan perannya yaitu ada yang sebagai pengajar dan ada yang sebagai peserta didik. Faktor yang mendukung kegiatan adalah antusiasme peserta untuk memahami konsep penerapan model pembelajaran inovatif untuk peningkatan kualitas pembelajaran di dalam kelas. Hal tersebutlah yang membuat kegiatan pelatihan ini dapat berjalan dengan lancar.

Selain faktor pendukung, tim pelaksana juga menemukan beberapa hal yang menjadi faktor penghambat dalam pelaksanaan pengabdian. Contohnya adalah kebijakan sekolah untuk membatasi jumlah guru yang antusias ingin ikut serta dalam pelaksanaan pengabdian demi kepentingan pembelajaran siswa di kelas. Tentu saja tim pelaksana merasa bersalah atas keinginan para guru yang tidak tercapai untuk dapat ikut serta dalam pelatihan. Namun tim tetap dapat mengerti situasi tersebut, sebab tugas utama guru adalah mengajar. Selain itu terdapat guru yang pamit keluar-masuk untuk mengecek kelas yang mereka tinggal sehingga materi yang didapat guru tersebut pun tidak utuh karena tertinggal saat keluar ruangan. Adanya faktor-faktor penghambat tersebut bukan halangan dalam mewujudkan kegiatan pelatihan model pembelajaran inovatif.

\section{Kesimpulan}

Model-model pembelajaran inovatif dipilih untuk dijadikan materi dalam pelatihan model pembelajaran inovatif di SMPN 7 Kota Bengkulu dengan tujuan agar dapat meningkatkan kualitas pembelajaran di kelas sekaligus meningkatkan profesionalitas guru sebagai pengajar. Hasil yang diperoleh setelah pelaksanaan pengabdian adalah adanya peningkatan pengetahuan para guru tentang model-model pembelajaran inovatif. Artinya dapat dikatakan bahwa pelaksanaan pelatihan model pembelajaran inovatif untuk guru SMPN 7 Kota Bengkulu telah berhasil. Antusiasme peserta ketika pelaksanaan pengabdian berlangsung dan peningkatan pengetahuan yang terjadi sebelum dan sesudah pelatihan dilaksanakan merupakan indikator yang menunjukkan bahwa pelatihan ini memberikan manfaat bagi guru baik dalam segi pengetahuan maupun profesionalitas diri sebagai seorang pengajar. Selain itu, faktor lain yang membuat pelatihan ini berhasil juga karena materi pelatihan yang diberikan sesuai dengan kebutuhan guru di SMPN 7 Kota Bengkulu.

\section{Saran}

Kegiatan pengabdian masyarakat berjudul "Pelatihan Model-Model Pembelajaran Inovatif untuk Guru DiSMP 7 Kota Bengkulu" berjalan dengan lancar dan peserta pelatihan terlihat antusias selama pelatihan berlangsung. Oleh karena itu, dapat disimpulkan kegiatan pengabdian berhasil dan bermanfaat bagi peserta pelatihan. Pelatihan ini diharapkan dapat meningkatkan kualitas pembelajaran yang terjadi di dalam kelas, di mana kegiatan pembelajaran tidak lagi hanya sekadar bermakna bagi para peserta didik tetapi juga menyenangkan untuk pendidik dan peserta didik. Hendaknya penerapan model pembelajaran inovatif dilaksanakan secara berkesinambungan oleh para guru di SMPN 7 Kota Bengkulu. 


\section{Ucapan Terima Kasih}

Penulis mengucapkan terima kasih kepada pihak FKIP Universitas Bengkulu yang telah memberi dukungan moral dan dana terhadap program pengabdian masyarakat ini.

\section{Referensi}

Astuti, P., \& Febrian, F. (2019). Diseminasi online multimedia pembelajaran matematika yang dikembangkan menggunakan videoscribe. Jurnal Anugerah: Jurnal Pengabdian Kepada Masyarakat Bidang Keguruan Dan Ilmu Pendidikan, 1(1), 19-24.

Widodo dll. (2017). Pelatihan model-model pembelajaran inovatif bagi guru-guru Bahasa Indonesia di bandar lampung. Prosiding Seminar Nasional Pengabdian kepada Masyarakat Berkarya dan Berinovasi untuk Bangsa, 57-62.

Sanusi, A. (1991). Studi pengembangan model pendidikan profesional tenaga kependidikan. Jakarta: Depdikbud IKIP Bandung.

Slavin, R.E. (2009). Cooperative learning: teori, riset dan praktik. Bandung: Nusa Media.

Sumaryati, S. (2013). Peningkatan kompetensi profesional guru melalui pelatihan model-model pembelajaran inovatif. Jurnal Inotek, 17(2), 140-150.

Undang-Undang nomor 20 Tahun 2003 tentang Sistem Pendidikan Nasional 